\title{
A agenda da reforma política no Brasil: autores, objetivos, êxito e fracasso $(1988-2010)^{* *}$
}

The political reform agenda in Brazil: authors, goals, success and failure (1988-2010)

O presente artigo aborda o tema da reforma política no Brasil ao analisar as Propostas de Emendas à Constituição (PECs) apresentadas no período de 1988 a 2010, que versavam sobre as regras do jogo político. Um dos fatos mais destacados pelos estudiosos dos processos de reforma constitucional no país refere-se ao pequeno grau de permanência e estabilidade da Carta promulgada em outubro de 1988. Segundo esses estudiosos, teríamos permanecido em uma espécie de "agenda constituinte" (Couto e Arantes, 2006, p. 41) com os sucessivos governos necessitando desenvolver boa parte de sua produção no plano constitucional. As reformas realizadas nas décadas de 1980 e 1990 nos âmbitos econômico, administrativo e social seriam um exemplo de como o país permaneceu imerso em grande experimentação institucional (Melo, 2005).

É importante destacar, no entanto, que esse processo de experimentação, além de não ser singularidade do Brasil, não ocorreu da mesma maneira no que se refere às regras do jogo político. As reformas de primeira geração, realizadas nos anos de 1980 e início dos anos 1990, com o objetivo

\footnotetext{
É professora do Departamento de Ciências Sociais da Universidade Federal de Juiz de Fora (UFJF), Minas Gerais. E-mail: <mendes_rocha@yahoo.com.br>.

** É mestranda do Departamento de Ciências Sociais da Universidade Federal de Juiz de Fora (UFJF), Minas Gerais. E-mail: <ra.goncalves3@gmail.com>.

*** Este artigo é um dos resultados do projeto de pesquisa"Reforma política na América Latina: uma análise comparada da agenda de reformas", desenvolvido na UFJF de 2011 a 2013. As autoras agradecem as valiosas contribuições dos pareceristas da RBCP.
} 
de estabilizar e liberalizar a economia, assim como as chamadas reformas de segunda geração, focadas nas estruturas regulatórias e na ampliação e aperfeiçoamento da provisão de serviços públicos, também foram colocadas em prática em outros países dentro e fora da América Latina, embora com ritmos e intensidades variadas (Melo, 2005).

Também no que se refere às instituições políticas, observou-se grande experimentação institucional nas novas democracias surgidas na esteira da terceira onda de democratização, mais uma vez, com diferentes graus de aprofundamento. No caso do Brasil, por exemplo, observa-se uma significativa distância entre a agenda de reformas - o que se debate e o que efetivamente se propõe, seja por meio de legislação infraconstitucional ou constitucional - e o que foi efetivamente implementado. Como afirma Rennó (2008, p. 16), atingir os acordos necessários à consecução das reformas não é tarefa fácil, uma vez que "o sistema político controla a alocação de recursos na sociedade, define ganhadores e perdedores, está baseado em valores e, em muitas instâncias, busca o equilíbrio entre valores díspares, como representatividade e governabilidade". Os riscos envolvidos na mudança institucional, as altas exigências para realizar alterações na Constituição e a dificuldade para atingir os amplos consensos necessários à sua consecução têm feito das reformas eventos raros em alguns países, entre os quais se inclui o Brasil (Rennó, 2008). Portanto, quando estudiosos referem-se ao pequeno grau de permanência e estabilidade da Carta promulgada em 1988, é provável que estejam se referindo mais às mudanças realizadas em outros âmbitos, como o econômico e o administrativo, do que propriamente às regras do jogo. Estas, ao contrário, têm demonstrado grande estabilidade e, embora o tema da reforma política esteja em evidência já há algum tempo no país, poucas mudanças com capacidade de provocar impactos significativos na dinâmica política foram implementadas desde 1988.

Os processos de mudança institucional levados a cabo na esteira da terceira onda de democratização nos países da América Latina e do Leste Europeu e as mudanças das regras do jogo em alguns países de democracia consolidada na década de $1990^{1}$ contribuíram para colocar em xeque a suposta estabilidade de determinadas instituições e resultaram em uma mudança de perspectiva na abordagem das instituições políticas. Estas, de estruturas 
estáveis a regularem o conflito e a competição, passaram a ser também consideradas objetos da luta, passíveis de serem transformadas pelos atores políticos (Lijphart e Grofman, 1984; Norris, 1997; Lijphart, 1994; Donovan, 1995; Jones, 1994; Zovatto e Henríquez, 2008). Observou-se, a partir de então, maior interesse em compreender quando, sob que condições e por que os atores políticos optam por alterar as regras do jogo, com destaque para o sistema eleitoral e, no caso das mudanças efetivamente realizadas, explicar sua direção e alcance (Boix, 1999; Colomer, 2005). Interesse também observado no contexto das novas democracias latino-americanas, nas quais a reforma política tem sido vista frequentemente como panaceia para várias deficiências das instituições e até mesmo de governos (Amorim Neto, Cortez e Pessoa, 2011; Negretto, 2009).

É nesse contexto que o tema da reforma política surge com destaque na agenda da academia e das próprias elites políticas latino-americanas. Uma vez instituído o novo arranjo político, após os processos de redemocratização, a questão passou a ser a de avaliar o seu funcionamento, sua capacidade para permitir o processamento, em bases estáveis, dos conflitos políticos em meio à ampla incorporação dos cidadãos e grupos sociais ao processo político.

No Brasil, como destaca Brussi (2008), o debate em torno do que se convencionou chamar de reforma política remete à própria Constituinte, quando se observaram divergências importantes, que culminaram em um acordo para a realização de uma revisão constitucional cinco anos depois, momento em que o tema da reforma deveria ser retomado. De lá para cá, o tema permaneceu na agenda política dividindo os estudiosos e as elites parlamentares. Debate-se a própria necessidade de uma reforma, o quê, como e quando reformar e a finalidade das mudanças (Rennó, 2008; Cintra, 2008).

É importante destacar que, embora neste artigo tenha se optado por abordar o tema com foco nas Propostas de Emenda à Constituição, a agenda da reforma política de modo algum se restringe às mudanças constitucionais. Muitas das regras importantes do jogo como o tipo de lista de votação, as regras para realização das campanhas e das coligações eleitorais e o modelo de financiamento das campanhas, entre outros, estão normatizadas em legislação infraconstitucional, sobretudo no Código Eleitoral de 1965 (Lei n. 4.737, de 15 de julho de 1965); na Lei n. 9.096, de 19 de setembro de 1995, que dipõe sobre os partidos políticos e regulamenta os artigos 17 e $14 \$ 3^{\circ}$, 
inciso V, da Constituição Federal; e na Lei n. 9.504, de 30 de setembro de 1997, que estabelece novas normas para as eleições. Portanto, como destaca Schmidt (2008, p. 53), as "linhas gerais das propostas dessa reforma oscilam entre medidas que exigem mudanças na própria Constituição Federal de 1988 e outras que estão no plano infraconstitucional". De fato, devido às altas exigências para efetivar mudanças na Constituição, uma opção dos reformadores têm sido a de focar sobre as mudanças que podem ser efetivadas por meio de legislação ordinária (Cintra, 2008)².

A opção por enfocar as Propostas de Emenda à Constituição justifica-se pelo fato de a maior parte das regras do jogo estar inscrita na Carta Magna, classificada por Soares (2006) como um tipo de constituição de ampla cobertura, em que, geralmente, há mais o que emendar e reformar. Segundo Couto e Arantes (2006, p. 54-55), a extensão e o grau de detalhamento da Constituição no que se refere à definição dos procedimentos que deveriam presidir o funcionamento da democracia no país pode ser resultado das "preocupações da época em torno da liberalização e da redemocratização do regime político". De fato, em um esforço de classificação dos dispositivos constitucionais, esses autores mostram que mais da metade dos dispositivos classificados como polity, que incluem as estruturas do regime, compreendendo os direitos individuais e as regras do jogo político, remete a estas últimas e que 855 , ou seja, 75,5\% dos dispositivos de polity da Constituição de 1988 "dizem respeito - exclusivamente ou em associação com outros - a definições de regras do jogo" (Couto e Arantes, 2006, p. 54) 3 $^{3}$.

Embora o tema da reforma política tenha ocupado bastante espaço na academia e na mídia brasileira motivando vários estudos, organização de coletâneas, realização de fóruns e seminários (Benevides, Vannuchi e Kerche, 2003; Soares e Rennó, 2006; Avritzer e Anastasia, 2006; Muhholand e Rennó, 2008) não se tem um amplo inventário das propostas de mudança que permita avaliar quais temas têm ganhado e quais têm perdido espaço no debate sobre a reforma das instituições políticas no

É o caso do Projeto de Lei (PL) n 2.679/2003, que propõe a adoção do voto em lista fechada preordenada, o fim das coligações em eleições proporcionais, o financiamento público de campanha, entre outros.

No que se refere a mudanças constitucionais, na agenda da reforma política, é importante distinguir, também, como propõe Couto (2006), as propostas de emenda constitucional que, em geral, possuem um caráter mais pontual dos processos especiais chamados de revisão constitucional de caráter mais abrangente e que podem resultar em alterações mais profundas. 
país. No que se refere especificamente às mudanças que implicam alterações constitucionais, pouco se sabe a respeito da agenda de reformas - do volume e do conteúdo das propostas apresentadas pelos diferentes atores ao longo dos anos. Afinal, a reforma política, em sua acepção mais ampla, não consiste apenas em modificações no sistema eleitoral e partidário, mas inclui questões relativas à relação entre os poderes e ao próprio processo legislativo (Rennó, 2008).

Neste artigo, propõe-se que uma etapa importante na compreensão dos processos de mudança institucional deveria ser a análise da própria agenda de reformas, isto é, das propostas apresentadas pelos atores institucionalmente legitimados para tal para mudar as regras do jogo democrático. Trata-se, aqui, de saber quais propostas têm perdido e quais têm ganhado espaço na agenda; quais são os principais problemas a que se destinam as propostas de mudança; quem são os proponentes das mudanças e qual tem sido o sucesso dos diferentes atores em fazer as propostas avançarem depois de apresentadas. Sabe-se que, nem sempre, ao propor um projeto de lei, os atores esforçam-se pela sua aprovação, podendo as emendas serem vistas apenas como forma de tomar posição perante a sociedade (Mayhew, 2006). Acredita-se, porém, que a persistência de determinados temas no conjunto das propostas apresentadas seja um bom indicativo das preferências das elites políticas por determinadas regras e instituições.

No caso do Brasil aventou-se a hipótese de que, devido à estabilidade política experimentada nas últimas décadas e ao desempenho positivo dos sucessivos governos nas áreas social e econômica, comparativamente a outros países da América Latina, propostas mais radicais de mudança teriam perdido espaço na agenda de reformas em favor de mudanças mais pontuais. Os prognósticos pessimistas sobre os impactos da combinação institucional sobre a governabilidade, bastante difundidos nos anos 1980 e 1990 na América Latina (Lamounier, 1989; Linz e Valenzuela, 1994; Mainwaring, 1993; Mainwaring e Shugart, 1997; Ames, 2001), teriam perdido credibilidade ao longo dos anos, à medida que o arranjo institucional se mostrou capaz de processar os conflitos em bases estáveis e favorecer a produção de resultados substantivos para uma maioria de cidadãos.

Tal hipótese não se baseia em uma avaliação inteiramente positiva do funcionamento do sistema, pois há que se considerar, como destacam alguns autores (Anastasia, Melo e Santos, 2004; Cintra, 2008), que o modus operandi 
do presidencialismo de coalizão no Brasil produz ganhos em termos de governabilidade, mas apresenta altos custos no que se refere à representatividade e à accountability do sistema. Quer-se dizer que, diante dos custos e dos riscos que a realização de uma reforma implica, as elites parlamentares optariam pela realização de mudanças mais pontuais como forma de aperfeiçoar o sistema e superar algumas de suas deficiências.

A averiguação dessa hipótese, que associa o contexto político e socioeconômico às preferências das elites em relação às instituições, dependeria de uma análise comparativa incluindo outros países. O objetivo do presente artigo é, entretanto, mais modesto, restringindo-se à análise da agenda de reformas no Brasil ao longo do tempo, passo importante para futuras investigações incluindo outros casos.

\section{A agenda de reformas: autores e temas}

Em seu artigo 60, a Constituição estabelece que as propostas de emenda podem ser apresentadas por um terço, no mínimo, dos membros da Câmara dos Deputados ou do Senado; pelo presidente da República, e por mais da metade das Assembleias Legislativas dos estados, manifestando-se, cada uma delas, pela maioria relativa de seus membros.

Neste artigo, foram analisadas as Propostas de Emenda Constitucional (PEC) apresentadas desde a promulgação da Constituição de 1988, em 5 de outubro, até o final do ano de 2010, e que tinham como objeto as regras do jogo político ${ }^{4}$. Foram consideradas apenas as propostas que tiveram origem na Câmara dos Deputados ou no Poder Executivo. Foram excluídas da análise as propostas que objetivavam alterar a divisão de competências entre os entes federados, as que definiam regras para perda de mandato dos parlamentares, definiam o total de gastos do Legislativo ou o valor da remuneração de membros do Poder Legislativo e do Executivo e as emendas relativas à organização e funcionamento do Poder Judiciário.

De 1988 a 2010, a Constituição de 1988 recebeu 2.606 propostas de emenda que versavam sobre os mais diferentes temas (ver Tabela 1 ). A análise que se segue baseou-se em um conjunto de 661 PECs que versavam sobre as regras

Este período compreende sete governos (Sarney, Collor, Itamar Franco, FHC 1, FHC 2, Lula 1 e Lula 2) e seis legislaturas (1987-1990; 1991-1994; 1995-1998; 1999-2002; 2003-2006; 2007-2010) na Câmara dos Deputados. 
políticas, excetuando-se os casos supracitados. Desse conjunto, $564(85,3 \%)$ delas continham apenas uma proposta de mudança. As demais continham de duas a sete propostas. Por essa razão, as 661 PECs apresentam, juntas, 808 propostas de modificação das regras do jogo. Ao longo do artigo, algumas análises tomarão como base o total de PECs e outras o total de propostas de mudanças contidas no total de PECs apresentadas no período.

Tabela 1 - Total de PECs x Total de PECs sobre regras políticas por legislatura (1988-2010)

\begin{tabular}{c|c|c}
\hline legislatura & total de PECs & total de PECs sobre regras políticas \\
\hline $1988-1990$ & 63 & $35(55,5 \%)$ \\
\hline $1991-1994$ & 192 & $64(33,3 \%)$ \\
\hline $1995-1998$ & 632 & $159(25,1 \%)$ \\
\hline $1999-2002$ & 598 & $156(26,1 \%)$ \\
\hline $2003-2006$ & 590 & $149(25,2 \%)$ \\
\hline $2007-2010$ & 531 & $98(18,4 \%)$ \\
\hline total & 2.606 & $661(25,4 \%)$ \\
\hline
\end{tabular}

Fonte: Elaboração própria com base nos dados do Sileg (Sistema de Informação do Legislativo), Câmara dos Deputados (Brasil, 1988-2010).

Os dados mostram que nos primeiros anos após promulgada a Constituição, mais da metade das propostas de emenda relacionava-se às regras do jogo político. Tratava-se, então, de uma questão central na preocupação das elites políticas. Do ano de 1991 em diante, embora tenha havido aumento no número de PECs sobre o tema, as mudanças nas regras políticas passaram a representar uma parcela reduzida do total, já que a agenda passou a ser frequentada por outras questões como as relativas à administração pública e ao sistema tributário. A análise por ano permitiria perceber que nos primeiros anos de cada legislatura (1995, 1999, 2003 e 2007) foi apresentado o maior volume de PECs, enquanto o último ano (1994, 1998, 2002 e 2010) apresenta um volume bem menor. Um padrão semelhante ao da produção legislativa como um todo como mostram vários estudos sobre o tema.

Das 661 PECs analisadas no período, apenas quatro tiveram origem no Poder Executivo. As demais foram de proposição de deputados (com a 
assinatura de um terço dos membros da Câmara dos Deputados). Obviamente, isso não quer dizer que, durante o período analisado, o Executivo tenha se alijado do jogo da mudança institucional. Ao contrário, como destaca Rennó (2008, p. 32), o Poder Executivo (ao lado do Judiciário) foi responsável por poucas mudanças no sistema, mas "todas foram adotadas e todas com impactos muito significativos, muito profundos no funcionamento do sistema político brasileiro enquanto estiveram em vigor". As mudanças realizadas por iniciativa do Legislativo, por seu turno, não alteraram profundamente o funcionamento do sistema eleitoral ou a relação Executivo-Legislativo. Por outro lado, não obstante aos custos de coordenação enfrentados pelo Poder Legislativo, não se pode negar - e os dados anteriores sobre a autoria das PECs comprovam - que "o Congresso tem sido o fórum privilegiado de discussão sobre reforma política" (Rennó, 2008, p. 35).

No período analisado, deputados de 25 partidos diferentes foram autores de PECs. Os maiores partidos em representação no período também originaram a maior parte das PECs apresentadas. Do total de 661 PECs analisadas, mais da metade tiveram origem no PMDB (18\%), PSDB (15\%), PFL $^{5}$ (14\%) e PT (9\%).

A análise da autoria por ideologia mostra que os deputados dos partidos de esquerda foram os que menos propuseram PECs: $21 \%$ do total, contra $35 \%$ dos partidos de centro e $43 \%$ dos partidos de direita ${ }^{6}$. O percentual de PECs apresentadas por deputados de esquerda aumenta a partir de 1999, mas nunca atingindo os $30 \%$ em cada legislatura e permanecendo sempre menor se comparado aos percentuais de PECs apresentadas por deputados de centro e de direita. Seria necessária uma análise mais detida para explicar esse fato não sendo possível inferir que entre os deputados dos partidos de esquerda haveria maior apoio ao status quo institucional.

\section{Conteúdo da agenda de reformas}

É possível classificar as 808 propostas contidas no total das PECs analisadas em nove grandes temas: (1) Sistema de governo; (2) Sistema de

No ano de 2007, o Partido da Frente Liberal (PFL) passou a se chamar Democratas (DEM).

A classificação dos partidos foi feita com base em Figueiredo e Limongi (1999), Melo (2004), Miguel e Machado (2010) e Praça e Dantas (2010). Sete PECs (1\%) foram propostas por deputados "sem partido". 
representação; (3) Direitos políticos; (4) Partidos políticos; (5) Sistema e processo eleitoral; (6) Executivo e Legislativo e organização e processo legislativo; (7) Participação popular; (8) Regras para mudança constitucional; e (9) Outros ${ }^{7}$ - ver Gráfico 1.

Gráfico 1 - Temas das propostas contidas nas PECs apresentadas no período (1988-2010)

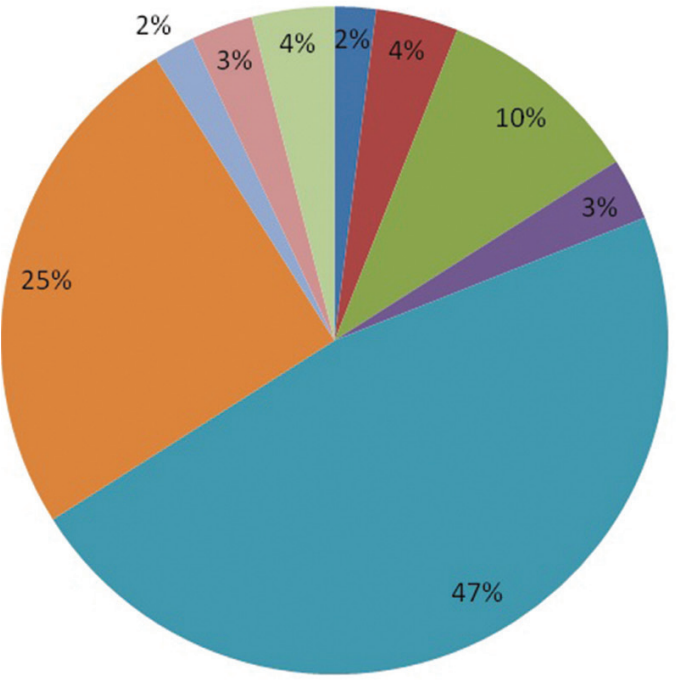

- Sistema de governo

—Sistema de representação

Direitos políticos

Partidos políticos

Sistema e processo eleitoral

EXE-LEG e organização/processc legislativo

- Participação popular

Regras para mudança constitucional

Outros

Fonte: Elaboração própria com base nos dados do Sileg (Sistema de Informação do Legislativo), Câmara dos Deputados (Brasil, 1988-2010).

No período analisado foram apresentadas 8 PECs para introduzir o sistema parlamentarista de governo, sendo 6 apresentadas nos anos de 1988, 1989 e 1990 ( 2 em cada ano). Das 8 PECs, 5 tiveram origem em partidos de direita. Depois de 1990, apenas em 1995 e 2004 foram apresentadas PECs com esse objetivo (uma em cada ano). Desde 2004, nenhuma proposta tendo como objeto o sistema de governo é apresentada na Câmara dos Deputados. De 1989 a 1993 foram apresentadas 10 PECs relacionadas ao tema, visando regular a realização do plebiscito pelo qual a população deveria decidir pela manutenção ou alteração da forma e do sistema de governo do país. No 
plebiscito realizado em 21 de abril de 1993, a manutenção da República foi a opção de $86,6 \%$ dos eleitores e $69,2 \%$ optaram pela manutenção do presidencialismo. O resultado certamente contribuiu para o desaparecimento do tema da agenda de reformas; este pode sugerir, também, que a desconfiança em relação ao presidencialismo, bastante difundida no início dos anos de 1990, tenha sido superada.

O sistema de representação foi objeto de propostas de mudança com maior frequência e durante um período mais longo de tempo comparativamente ao sistema de governo. Foram 9 PECs para introduzir o sistema majoritário, 20 para introduzir o sistema misto na eleição dos legisladores e uma para tornar todas as eleições legislativas proporcionais. A introdução do sistema majoritário entrou na pauta no ano de 1995 e a proposta mais recente data de 2007. Já a introdução do sistema misto foi proposta em todas as legislaturas, com exceção da de 1999-2002, e a proposta mais recente data de 2010. A maior parte das propostas foi apresentada na década de 1990, mas, o tema ainda encontra espaço entre os parlamentares e pode-se dizer que talvez seja a proposta de maior impacto a frequentar a agenda da reforma política hoje no Brasil, ao lado da proposta de alteração do tipo de lista de votação, que pode ser realizada por meio de legislação ordinária.

Das 29 PECs que visavam introduzir o sistema misto ou majoritário, 23 foram apresentadas por deputados de partidos que podem ser considerados médios ou grandes para os padrões de fragmentação parlamentar da Câmara dos Deputados. Justamente aqueles que, como demonstra largamente a literatura sobre o tema (Lijphart, 2003), tendem a se beneficiar mais sob a vigência daquelas regras (o quanto eles são beneficiados depende de outros atributos do sistema como a magnitude dos distritos, por exemplo). Apenas 4 PECs tiveram origem em partidos pequenos.

Se a dimensão do cálculo estratégico parece estar presente na proposição dessas mudanças, é importante registrar que das 29 PECs que objetivavam a introdução do sistema misto ou do sistema majoritário, apenas uma teve origem em um partido de esquerda. Esse fato sugere que a dimensão ideológica também deve ser levada em conta para se compreender a direção das mudanças propostas. Pode-se aventar a hipótese a ser testada em futuras investigações de que os membros dos partidos de esquerda, tradicional- 
mente comprometidos com o princípio da inclusão, tenham preferência pelo sistema proporcional e, logo, tendam a apoiar a manutenção do status quo no que se refere ao sistema de representação.

Foram identificadas 85 propostas $(10,5 \%$ do total) que tinham como objeto os direitos políticos. Entre eles, a introdução do voto facultativo (19 no total, sendo 13 apresentadas na década de 1990 e a última no ano de 2007), a extensão dos direitos de votar e de se candidatar, restrições à elegibilidade, mudança da idade mínima para se candidatar aos diferentes cargos eletivos (20 no total) e mudança nas regras relacionadas ao registro de candidaturas. Como no ano de 1985 foi extinta a última barreira ao direito de voto no Brasil - a alfabetização -, restando somente a exigência de idade mínima, as propostas que versavam sobre o direito de votar e se candidatar referiam-se a situações muito específicas, como a extensão de direito de voto a estrangeiros domiciliados no Brasil ou à proibição/permissão de eleição de parentes de detentores de cargos eletivos.

Na categoria "partidos políticos" foram incluídas 22 PECs que tinham como objetivo introduzir a fidelidade partidária e/ou impor penalidades aos parlamentares que se desfiliassem dos partidos pelos quais foram eleitos. Destas, 13 foram apresentadas na legislatura 1995-1998. As duas últimas propostas com esse teor foram apresentadas no ano de 2007, quando o Supremo Tribunal Federal (STF) estabeleceu que, no caso das eleições proporcionais, os mandatos dos deputados pertenciam aos partidos pelos quais eles se elegeram. A partir de então, os partidos poderiam reaver as cadeiras perdidas em função da migração partidária. Um dado curioso é que, das 22 PECs que objetivavam introduzir a fidelidade partidária e conter a migração, a maioria (82\%) foi proposta por membros de partidos da base de apoio ao governo que, tradicionalmente, era o maior beneficiado pela migração (Melo, 2004).

$\mathrm{Na}$ categoria "sistema e processo eleitoral" foi agrupada a maior parte das PECs que tratavam dos mais diversos temas (ver Gráfico 2). O sistema eleitoral é composto por um conjunto de regras que definem como se constitui a representação. Essas regras definem o número e os tipos de atores com direito a voz no processo político e dão, pelo menos em parte, as condições para o exercício do governo. 
Gráfico 2 - Propostas que versavam sobre o sistema e o processo eleitoral (1989-2010)

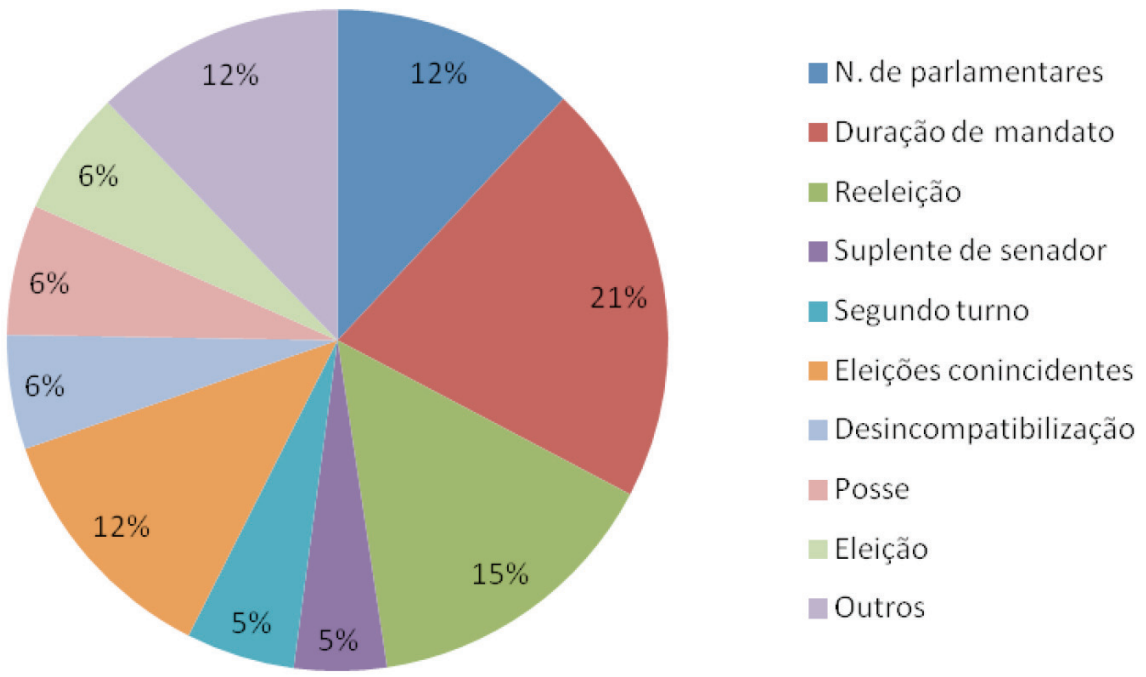

Fonte: Elaboração própria com base nos dados do Sileg (Sistema de Informação do Legislativo), Câmara dos Deputados (Brasil, 1988-2010).

Para além do sistema de representação, tratado separadamente, outros componentes do sistema eleitoral objeto de propostas de alteração foram: a magnitude dos distritos eleitorais, a duração dos mandatos, a permissão ou não para reeleição, a existência ou não de segundo turno, as regras para distribuição dos restos, a existência ou não de cláusula de barreira, entre outros. No total foram contabilizadas 376 propostas (46,5\% do total de propostas e não de PECs) relacionadas ao sistema e ao processo eleitoral.

Embora não seja um tema central nos debates sobre a reforma política no país, o estabelecimento da coincidência geral das eleições foi uma proposta muito frequente no período de 1988-2010. Versavam 46 PECs sobre este tema, prevendo, como forma de operacionalizar a unificação das eleições, a alteração na duração dos mandatos (sobretudo de prefeitos e vereadores) e a proibição da reeleição. As propostas para tornar as eleições coincidentes estiveram presentes em todas as legislaturas crescendo uma após a outra. Tal proposta teve origem em quinze partidos diferentes que estiveram representados na Câmara, no período, principalmente nos de maior representação como PMDB, PFL, PSDB, PPB, PP, PTB e PT. 
Os defensores da unificação das eleições argumentam que a mudança contribuiria para reduzir os gastos com eleições no país, impedir que detentores de cargos eletivos abandonem suas funções antes do término do mandato para se candidatar a outros cargos e para evitar que, de dois em dois anos, as atividades do Congresso sejam parcialmente paralisadas devido ao envolvimento dos parlamentares nas eleições municipais. Outro argumento favorável baseia-se na ideia de que a coincidência geral das eleições promoveria a harmonização administrativa entre os entes federativos, evitando o engessamento da administração municipal e assegurando a continuidade na realização de obras e programas. Os que argumentam contrariamente à unificação acreditam que ela tornaria o processo eleitoral mais confuso para os eleitores que passariam a ter que escolher de sete a oito candidatos em um único pleito. Além disso, argumenta-se que as eleições separadas contribuem para maior dispersão de poder nas três esferas de governo favorecendo a accountability vertical, permitindo aos eleitores "sinalizar suas avaliações para os representantes no momento em que alguns mandatos ainda estão em curso" (Anastasia, Melo e Santos, 2004, p. 97).

Talvez a maior dificuldade em fazer a proposta avançar ${ }^{8}$ deva-se à resistência dos vereadores e prefeitos em exercício em verem seus mandatos reduzidos ou, daqueles que pretendem se candidatar a esses cargos, de verem os mandatos dos atuais ocupantes prorrogados. Além disso, uma vez unificadas as eleições, os deputados federais podem não contar com o apoio integral, em seus redutos eleitorais, dos prefeitos e vereadores que, engajados em sua própria reeleição, poderão não se prestar ao papel de cabos eleitorais que normalmente desempenham.

No período analisado, foram contabilizadas 78 propostas de alteração na duração dos mandatos para cargos no Executivo e no Legislativo 9 . Propostas deste teor foram apresentadas em 17 dos 23 anos analisados. Os anos com maior número de PECs com esse objetivo foram 1995, 1999, 2003 e 2007, sempre um ano depois das eleições nacionais. As propostas mais frequentes visavam introduzir alterações na duração dos mandatos de prefeitos, verea-

\footnotetext{
Desde 2004 está pronta para ser votada no Plenário da Câmara a PEC 3/1999 que prevê que os mandatos de prefeitos e vereadores terão, excepcionalmente, a duração de seis anos a partir da promulgação da proposta para que haja coincidência de eleições. Uma proposta semelhante tramita no Senado, mas propõe excepcionalmente a redução, e não a prorrogação dos mandatos de prefeitos e vereadores. A Constituição de 1988 previa uma revisão constitucional cinco anos depois. No ano de 1994, o mandato presidencial foi reduzido de cinco para quatro anos (Emenda Constitucional de Revisão n 5, de 7 de junho de 1994).
} 
dores e senadores. O número elevado de propostas de alteração da duração dos mandatos no nível municipal deve-se ao fato de que grande parte das PECs que versam sobre esse assunto tratava também do estabelecimento da coincidência geral das eleições no país. A maior parte dessas PECs propunha a prorrogação dos mandatos de vereadores e prefeitos por uma única vez (mandato tampão), de modo a tornar as eleições coincidentes. A maioria das propostas relativas à duração do mandato de deputados, governador e presidente visava à sua ampliação para cinco anos. Apenas em relação aos senadores é que predominam as propostas de redução do mandato.

Outra proposta bastante comum no período analisado versava sobre a reeleição, sobretudo para os cargos executivos. De 1989 a 2010 foram apresentadas 56 propostas com este teor (ver Tabela 2).

Tabela 2 - Propostas introduzindo permissão/proibição para reeleição para cargos no Executivo e no Legislativo (1989-2010)

\begin{tabular}{c|c|c|c|c|c}
\hline & parlamentares & $\begin{array}{c}\text { governadore } \\
\text { prefeito }\end{array}$ & presidente & $\begin{array}{c}\text { chefes } \\
\text { executivo }\end{array}$ & prefeito \\
\hline introduz & 0 & 0 & 1 & 8 & 0 \\
\hline proíbe & 0 & 2 & 0 & 35 & 1 \\
\hline limita/estabelece restrições & 4 & 0 & 3 & 1 & 1 \\
\hline total & 4 & 2 & 4 & 44 & 2 \\
\hline
\end{tabular}

Fonte: Elaboração própria com base nos dados do Sileg (Sistema de Informação do Legislativo), Câmara dos Deputados (Brasil, 1988-2010).

A introdução da reeleição consecutiva (limitada a uma única vez) para os cargos de presidente, governador dos estados e do Distrito Federal e prefeitos se deu por meio da Emenda Constitucional $n^{\circ} 16$, de 4 de junho de 1997. A emenda resultou da aprovação da PEC no 1/1995, de autoria de um deputado do PFL, à época principal aliado da coalizão de apoio ao presidente Fernando Henrique Cardoso. Uma proposta com o mesmo teor já tinha sido apresentada em 1989, e, embora tenha passado pela Comissão de Constituição e Justiça e de Cidadania (CCJC) e pela Comissão Especial, não foi à frente. No ano de 1995, outras 7 propostas introduzindo a reeleição para os cargos executivos e/ou para presidente foram apresentadas, mas tiveram sua tramitação sujeitada à da $\mathrm{PEC} \mathrm{n}^{\circ} 1 / 1995$, que acabou sendo transformada em norma jurídica após dois anos e 108 dias de tramitação. 
De 1999 a 2009, 35 propostas proibindo a reeleição para cargos executivos foram apresentadas e outras 7 estabeleciam limites e restrições. $O$ interessante a notar é que elas tiveram origem tanto nos partidos da coalizão como nos que não faziam parte dela, em proporção semelhante. A grande frequência de PECs com esse teor remete a um aspecto assinalado por Rennó (2008): o fato de que as mudanças institucionais não requerem um consenso apenas ex ante, mas dependem, também, de um consenso ex post, resultado da avaliação de seus impactos sobre o funcionamento do sistema. Há sempre a possibilidade de reversão da decisão anterior. No caso da reeleição, as tentativas de reversão da mudança podem resultar mais de uma insatisfação com a forma como ela foi conduzida - em termos muito casuísticos, em ano pré-eleitoral, com benefícios diretos para os que ocupavam cargos executivos à época, como o então presidente da República - do que de uma avaliação ponderada de seus impactos. Um contraponto interessante pode ser feito com a decisão tomada por meio do plebiscito de 1993, que reafirmou o presidencialismo como sistema de governo: após a sua realização, as propostas visando à substituição do presidencialismo reduziram drasticamente e deixaram de vez a agenda de reformas em um sinal de que o tema teria sido dado por encerrado mediante a consulta aos cidadãos.

Outra proposta de mudança bastante comum relaciona-se ao número de parlamentares. De 1989 a 2010, foram apresentadas 45 propostas versando sobre esse tema (Ver Tabela 3). Trata-se de propostas de mudança com grande impacto sobre o funcionamento do sistema, uma vez que a magnitude dos distritos eleitorais têm consequências significativas sobre o grau de desproporcionalidade dos resultados, sendo, segundo alguns autores, fator mais decisivo do que a própria fórmula eleitoral (Taagepera e Shugart, 1989; Lijphart, 2003). No Brasil, discutem-se, sobretudo, as distorções provocadas pelo estabelecimento de um número mínimo e máximo de cadeiras na Câmara, que leva à sub-representação dos estados mais populosos e à sobrerrepresentação dos menos populosos (Nicolau, 1997, 2004).

As propostas mais comuns foram de alteração do número de deputados federais, ampliando ou alterando os números mínimo e máximo por estado, e de modificação no número de vereadores ${ }^{10}$. Esta última chegou a ser imple-

10 Desde 1988, a composição da Câmara dos Deputados foi alterada duas vezes, passando de 495 para 503 em decorrência da transformação dos territórios do Amapá e de Roraima em estado no ano de 1991; e de 503 para 513 devido à ampliação da bancada de São Paulo de 60 para 70 deputados por meio de lei complementar. 
mentada, mas por meio de uma PEC do Senado, que deu origem à Emenda Constitucional $n^{\circ}$ 58/2009 estabelecendo o número máximo de vereadores proporcionalmente à população dos municípios.

Tabela 3 - Propostas que versavam sobre número de parlamentares (1989-2010)

\begin{tabular}{c|c|c|c|c}
\hline & vereador & $\begin{array}{c}\text { deputado } \\
\text { estadual }\end{array}$ & $\begin{array}{c}\text { deputado } \\
\text { federal }\end{array}$ & senador \\
\hline amplia & 1 & 0 & 0 & 0 \\
\hline reduz & 1 & 2 & 14 & 3 \\
\hline modifica* $^{*}$ & 11 & 1 & 12 & 0 \\
\hline total & 13 & 3 & 26 & 3 \\
\hline
\end{tabular}

Fonte: Elaboração própria com base nos dados do Sileg (Sistema de Informação do Legislativo), Câmara dos Deputados (Brasil, 1988-2010).

* Altera os números mínimo e máximo; define regras para definição do número.

A introdução de um percentual mínimo de votos para os partidos terem funcionamento parlamentar pleno no Congresso não foi objeto de muitas propostas no período. Apenas 6 PECs tratavam do tema que está presente na agenda desde o ano de 1989. As últimas propostas com esse teor foram apresentadas em 2002 e $2009^{11}$.

Outras propostas menos frequentes relacionadas ao sistema e ao processo eleitoral foram: (a) as que determinavam a necessidade de renúncia/ licença do cargo para chefes do executivo e parlamentares concorrerem à reeleição e /ou estabeleciam prazo para a desincompatibilização; (b) as que aboliam ou introduziam o segundo turno nas eleições majoritárias. Mais especificamente, 11 propunham a extinção do segundo turno, sobretudo, nas eleições para prefeito e governador; 7 propunham a sua introdução em todas as capitais ou municípios com mais de 60 e/ou 100 mil eleitores; (c) as que versavam sobre a eleição de suplentes de senadores e os critérios para a sua convocação. A grande maioria determinava que os suplentes

\footnotetext{
1 A cláusula de barreira chegou a ser instituída no Brasil pela Lei n 9.096, de 1995, aplicada pela primeira vez nas eleições de 2006. O resultado foi a restrição dos direitos de 22 partidos que não atingiram o percentual mínimo de votos exigidos. Porém, em dezembro do mesmo ano, essa Lei foi declarada inconstitucional pelo Supremo Tribunal Federal mediante uma ação direta de inconstitucionalidade perpetrada pelos partidos que haviam sido prejudicados por sua introdução. Outra alteração revertida foi a regra da verticalização instituída pelo Tribunal Superior Eleitoral para as eleições de 2002 por meio de uma interpretação da legislação já existente.
} 
fossem os candidatos mais votados e não eleitos. Outras visavam reduzir o número de suplentes, proibir a eleição de suplente que fosse cônjuge e/ ou parente do titular e estabelecer caráter temporário para a convocação de suplente ${ }^{12}$.

O debate em torno da reforma política no Brasil é bastante dominado por propostas relacionadas aos sistemas partidário e eleitoral. Pouco se debate sobre as propostas de alteração do padrão de distribuição de poderes entre Executivo e Legislativo ou sobre a organização e o processo legislativo. Entretanto, a análise das PECs apresentadas no período de 1988 a 2010 mostra que propostas com esse teor foram frequentes, somando um total de 202 ou um quinto do total (considerando-se o total de propostas e não de PECs). Se parte importante da dinâmica política brasileira tem sido compreendida a partir das prerrogativas constitucionais do Executivo e da organização interna do Legislativo (Figueiredo e Limongi, 1999, 2006), essa dimensão da reforma política deveria receber maior atenção dos estudiosos do tema.

De 1988 a 2010 foram apresentadas 67 propostas que tinham como objeto as prerrogativas do Poder Executivo (ver Gráfico 3). Apenas 6\% delas visavam ampliar suas competências e poderes. As demais destinavam-se a extinguir, limitar, restringir e/ou regular o uso de determinadas prerrogativas e direitos do presidente da República; 15\% visavam reduzir o controle do Poder Executivo no processo de execução orçamentária por meio da introdução de caráter impositivo à lei orçamentária ou da proibição do contingenciamento de recursos pelo Executivo.

Mais da metade das PECs que versava sobre o assunto (59\%) tinha como objeto as Medidas Provisórias. A Emenda Constitucional n 32, de 2001, resultante da PEC n 472/1997, com origem no Senado, regulou os requisitos materiais de edição das Medidas Provisórias (MPs). O interessante a notar é que mesmo depois da aprovação da Emenda Constitucional no 32 , o instituto da medida provisória continuou sendo objeto de outras propostas de emenda constitucional (25 no total), visando à sua completa eliminação ou ao estabelecimento de regras que restringem e limitam o seu uso.

2 Segundo Araújo (2011), de 1989 a 2006, de todos os legisladores que passaram pelo Senado, 22,7\% deles eram suplentes. 
Gráfico 3 - PECs que versavam sobre prerrogativas do Poder Executivo (1989-2010)

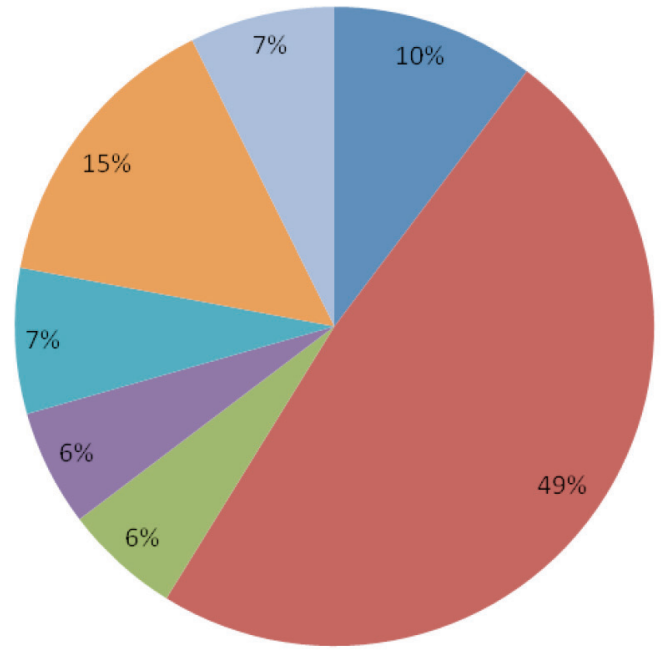

\author{
Extingue as MPS \\ Restringe/define regras para uso \\ de MPs \\ Reduz/restringe iniciativa \\ legislativa/competência \\ Amplia iniciativa/competência \\ - Limita escolha de ministros e \\ magistrados \\ - Dá caráter impositivo ao \\ orçamento/emendas \\ parlamentares \\ Outros
}

Fonte: Elaboração própria com base nos dados do Sileg (Sistema de Informação do Legislativo), Câmara dos Deputados (Brasil, 1988-2010).

Das 68 PECs que versavam sobre prerrogativas do Legislativo, mais da metade (62\%) visava ampliar tais prerrogativas e as competências exclusivas do Congresso Nacional em relação a temas substantivos e questões procedimentais, e permitir a convocação pelas duas casas do Congresso de autoridades (ministros, secretários, presidentes e diretores de estatais, do Banco Central, de agências reguladoras e de órgãos de administração indireta) para prestar esclarecimentos. No período de 1988 a 2010, apenas 5 PECs visavam reduzir as prerrogativas do Legislativo.

A análise ao longo do tempo revela que as PECs com intento de modificar a distribuição de poderes entre Executivo e Legislativo estão presentes na agenda de reformas desde a legislatura de 1988-1990, mas tiveram substancial aumento a partir dos governos de FHC e Lula. Ver Gráfico 4. 
Gráfico 4 - PECs que versavam sobre prerrogativas do Poder Legislativo (1989-2010)

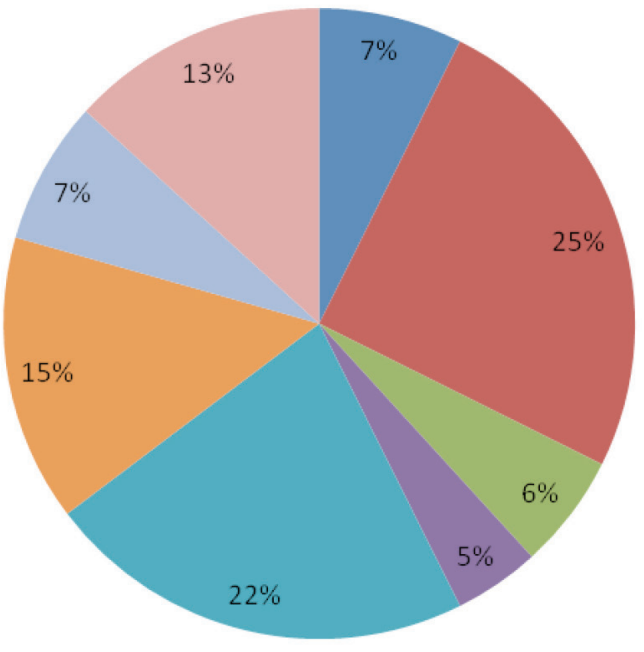

\author{
Poderes de investigação para \\ comissões permanentes e CPIs \\ - Convocação de \\ autoridade/pedido de \\ informação \\ Escolha de ministros do \\ STF/TCU \\ - Controle dos atos e omissões \\ das agências do Executivo \\ Amplia competências \\ procedimentos \\ Amplia competencias temas \\ substantivos
}

Fonte: Elaboração própria com base nos dados do Sileg (Sistema de Informação do Legislativo), Câmara dos Deputados (Brasil, 1988-2010).

Parte importante da literatura no campo dos estudos legislativos no Brasil chama a atenção para a importância de variáveis organizacionais para a compreensão do comportamento legislativo e das relações entre os poderes. Propõe-se que o comportamento dos parlamentares seja investigado não apenas a partir dos incentivos gerados pelas instituições básicas (sistema de governo, eleitoral e partidário), mas também das microinstituições (Figueiredo e Limongi, 1999, 2006; Amorim Neto, 2000; Amorim Neto e Santos, 2003). Estas distribuem prerrogativas e recursos entre governo e oposição e entre parlamentares, líderes partidários e comissões no interior do Legislativo e, dessa forma, impactam suas chances de influenciar a agenda e o ritmo dos trabalhos legislativos.

A organização interna da Câmara dos Deputados pode ser modificada pela reforma do Regimento Interno, mediante projeto de resolução de iniciativa de deputado, da Mesa, de Comissão Permanente ou de Comissão Especial para esse fim, criada e com deliberação da câmara (Art. 216 RI CD). 
Apesar disso, foi possível identificar 67 PECs versando sobre o tema. A maior parte delas tinham como objetivo ampliar a duração da sessão legislativa (na maioria dos casos com a redução do recesso parlamentar), instituir o voto aberto para todas ou algumas votações da Câmara dos Deputados e alterar as regras para apreciação do veto do Executivo ${ }^{13}$. Ver Gráfico 5.

Gráfico 5 - PECs que versavam sobre a organização e o processo legislativo (1989-2010)

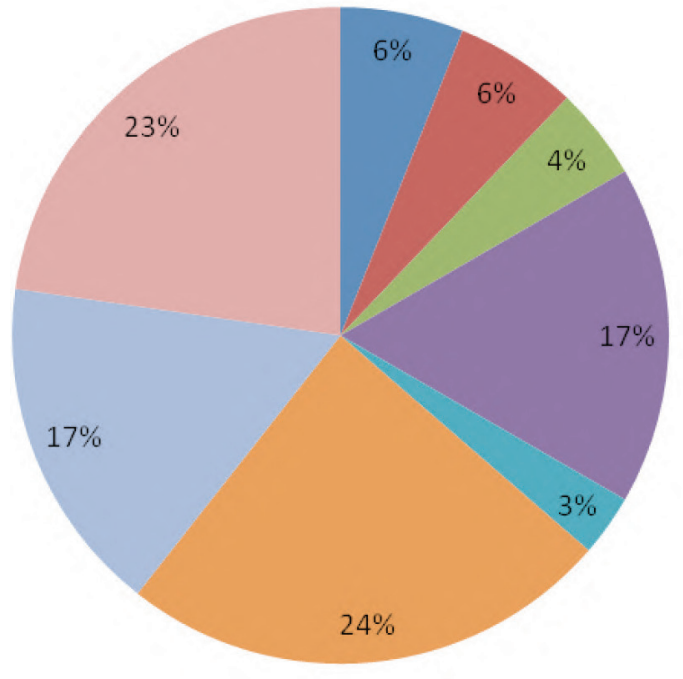

Processo orçamentário

Reeleição Mesa Diretora

Proporcionalidade Mesa

Diretora e/ou Comissões

Voto aberto

Duração mandato Mesa

Diretora

Duração sessão legislativa

Apreciação de veto

Outros

Fonte: Elaboração própria com base nos dados do Sileg (Sistema de Informação do Legislativo), Câmara dos Deputados (Brasil, 1988-2010).

Este último conjunto de propostas analisadas mostra que a reforma política no Brasil não consiste apenas em uma reforma do sistema eleitoral. Parte não desprezível das propostas apresentadas de 1988 a 2010 tinha como objeto as regras que distribuem prerrogativas entre os poderes e as que orientam a organização e o processo legislativo. O teor da maior parte das propostas demonstra um interesse, entre as elites parlamentares, de fortalecer o Poder Legislativo vis-à-vis o Executivo, sobretudo, pela limitação do uso

\footnotetext{
${ }^{13}$ Em novembro de 2013, como um dos desdobramentos das manifestações ocorridas em junho em várias partes do Brasil, o Senado aprovou, em segundo turno, a PEC que previa o fim do voto secreto em processos de cassação de mandato parlamentar e análise de vetos presidenciais. A votação secreta foi mantida para eleição dos membros da Mesa Diretora da Câmara e do Senado e indicações de autoridade como ministros do Supremo Tribunal Federal e do procurador-geral da República.
} 
das Medidas Provisórias pelo segundo e pela ampliação das competências do primeiro, tanto em relação a procedimentos como a temas substantivos.

Outro tema contemplado nas propostas de mudança relaciona-se à participação popular no processo legislativo. A Constituição de 1988 incorporou amplas formas de participação direta dos cidadãos tanto em nível nacional como local. Entre elas, está a participação direta por meio de plebiscitos, referendos e iniciativa popular e a participação por meio dos conselhos setoriais de políticas públicas (Avritzer, 2006) ${ }^{14}$. No período analisado, 15 PECs tratavam do tema da participação popular introduzindo novas prerrogativas aos cidadãos e entidades representativas, introduzindo novos mecanismos de participação e reduzindo o número mínimo de assinaturas exigido para apresentação de projeto de iniciativa popular de lei.

O último tema reuniu as propostas que propunham modificações nas regras para modificar a Constituição ou as propostas relativas à revisão constitucional. Juntas elas somam 24 propostas.

$\mathrm{Na}$ categoria outros, 35 PECs foram classificadas. Entre elas, 15 versavam sobre a licença/renúncia de parlamentar para ocupação de cargos na administração pública, definindo situações nas quais seria facultado aos parlamentares preservarem o mandato. A relevância da questão deve-se ao fato de ser comum, no Brasil, que ministros e secretários de Estado e diretores de empresas públicas sejam recrutados em meio a deputados e senadores, o que, por sua vez, contribui para elevar o número de suplentes em exercício.

\section{Tramitação: êxito e fracasso}

Segundo o Artigo 60 da Constituição Federal, uma PEC, para ser aprovada, necessita ser discutida e votada em cada casa do Congresso Nacional, em dois turnos, e obter em ambos, três quintos dos votos dos respectivos membros. Além disso, estabelece que matéria constante de proposta de emenda rejeitada ou havida por prejudicada não pode ser objeto de nova proposta na mesma sessão legislativa.

\footnotetext{
14 Desde 1988 foram realizados um plebiscito (para definir a forma e o sistema de governo, em 1993) e um referendo (para decidir sobre a proibição ou não da comercialização de armas de fogo, em 2005), e foram aprovadas, em nível nacional, quatro leis resultantes de projetos de iniciativa popular. No que diz respeito a esse último mecanismo, o número reduzido de propostas pode ser explicado pelas exigências constitucionais para a apresentação de um projeto desta natureza: a iniciativa, para ser apresentada ao Congresso Nacional, necessita ser subscrita por 1\% do eleitorado distribuído por, pelo menos, cinco estados com não menos de 0,3\% do eleitorado em cada um deles (Avritzer, 2006).
} 
Após ser protocolada na Mesa Diretora, a PEC é enviada à Comissão de Constituição e Justiça e de Cidadania (CCJC), onde é designado um relator para emitir parecer sobre a constitucionalidade da matéria. Se a matéria tiver parecer pela admissibilidade aprovado, o presidente da Mesa ordena a criação de uma comissão especial para apreciá-la e os partidos indicam os membros que deverão compor a comissão. Se tiver parecer aprovado na comissão especial, a matéria segue para votação em plenário em primeiro turno. Se aprovada, é votada em segundo turno. Finalmente, se aprovada, é enviada à casa revisora.

Entretanto, ao longo desse processo, muitos fatos podem impedir sua continuidade. É bastante comum que depois de apresentadas, muitas propostas sejam devolvidas ao autor por não conter o número mínimo de assinaturas (ou por problemas na validação das assinaturas). Depois de serem encaminhadas à CCJC, muitas propostas não seguem em frente devido à não indicação de relator ou à sua não inclusão na pauta de votações da comissão. As que passam pela CCJC param no caminho devido à não criação da comissão especial ou não designação de membros para compô-la. Depois de serem votadas na comissão especial, se aprovadas, as PECs ainda enfrentam outro ponto de veto: a decisão do presidente da casa em colocar o tema na pauta de votações do plenário. Se a PEC chega à casa revisora, qualquer mudança proposta deve ser apreciada e votada na casa de origem.

Segundo Couto (2006), as exigências para emendamento constitucional no Brasil são relativamente menores do que em outros países, o que pode ser evidenciado pelo alto índice de emendamento constitucional em termos comparativos (considerando-se o período de 1989 a 2012, ter-se-ia uma média de 2,9 emendas por ano). Isso não invalida o fato de que, para ser aprovada, uma PEC necessita passar por várias etapas e enfrentar vários pontos de veto. Os dados sobre tramitação das PECs analisadas evidenciam esse fato.

A maioria das PECs analisadas (82,7\% do total) sequer chegou a ser votada na CCJC. Apenas 114 PECs tiveram parecer votado na CCJC (17,3\% do total), 23 PECs (3,5\%) foram votadas em comissão especial; 11 (1,7\%) foram votadas no plenário em primeiro turno e apenas 7 (1\%) chegaram a ser votadas no plenário em segundo turno.

A CCJC (Comissão de Constituição e Justiça e de Cidadania) funciona como gatekeeper de duas formas: simplesmente não incluindo uma PEC na pauta de votações, levando ao seu arquivamento ao final da legislatura; ou aprovando um parecer pela inadmissibilidade. Se a PEC é declarada 
inconstitucional, ela é imediatamente arquivada, a não ser que seja apresentado recurso assinado por um décimo dos membros da casa no prazo de cinco sessões (Art. 58 CF 1988).

O parecer da CCJC, mesmo quando pela admissibilidade da PEC, pode vir acompanhando de substitutivos e emendas. Além disso, a aprovação do parecer pode ser por unanimidade, com a apresentação de votos contrários ou de voto em separado (Art. 57, RI CD). Algumas PECs podem ter parecer pela admissibilidade aprovado em um curto período de tempo, no mesmo ano em que foi apresentada ou na mesma legislatura. Outras, no entanto, podem ter de enfrentar um longo rito que envolve arquivamentos, desarquivamentos, pedidos de vistas, requerimentos, apensação a outras PECs, troca de relatores etc.

Do total de 114 PECs votadas na CCJC no período analisado, 59\% tiveram parecer pela admissibilidade aprovado por unanimidade; 79,8\% foram votadas na CCJC na mesma legislatura em que foram apresentadas e 53,5\% tiveram parecer pela admissibilidade aprovado por unanimidade na mesma legislatura. Apenas 11 PECs (10\% do total) receberam parecer pela inadmissibilidade e nenhum deles foi alvo de recurso por parte dos deputados. Ver Gráfico 7.

Gráfico 6 - Parecer da CCJC às PECs votadas na Comissão (1988-2010)

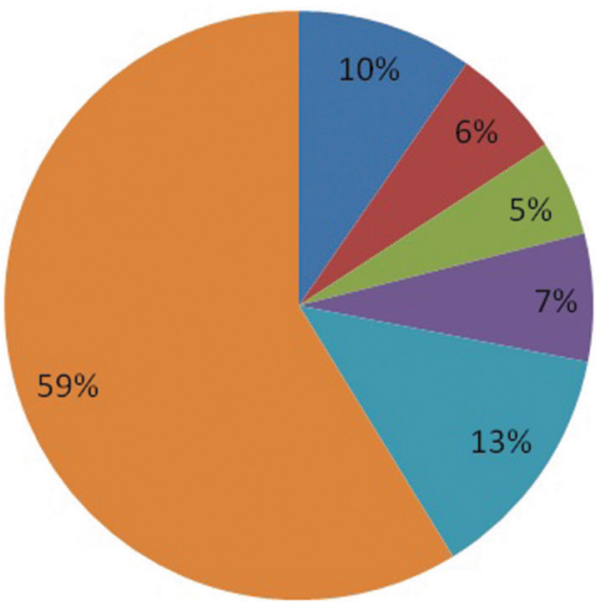

- Inadmissibilidade

Admissibilidade com substitutivo

Admissibilidade com emenda

Admissibilidade com voto em separado

Admissibilidade com voto contrário

Admissibilidade com unanimidade

Fonte: Elaboração própria com base nos dados do Sileg (Sistema de Informação do Legislativo), Câmara dos Deputados (Brasil, 1988-2010). 
É importante ter em mente que os deputados federais contam com uma assessoria própria e uma institucional, que lhes permitem se antecipar a um eventual parecer negativo da comissão: eles são advertidos, antes, sobre a inconstitucionalidade de uma proposta de sua autoria. Nesse caso, podem optar por retirá-la ou mantê-la. Pode mantê-la, mesmo sabendo que ela não será acatada pela comissão, apenas como forma de sinalizar para seus eleitores o seu empenho em torno de alguma causa. Esse fato pode explicar o número muito pequeno de PECs não admitidas pela CCJC no período.

$O$ pequeno percentual de PECs que receberam parecer pela inadmissibilidade e o grande percentual de PECs votadas na mesma legislatura em que foram apresentadas sugere que a CCJC exerce seu poder de veto mais pela não apreciação dos projetos do que por sua rejeição e posterior arquivamento. Uma análise mais detida das PECs que passaram pela CCJ e avançaram para os demais estágios do processo pode contribuir para compreender alguns fatores associados ao maior ou menor êxito das propostas.

O primeiro fato a destacar é a progressiva redução da proporção de PECs votadas na CCJC considerando o total de PECs apresentadas. Se, na legislatura de 1988-1990, mais da metade das PECs apresentadas chegou a ser votada na CCJC, na última legislatura analisada, de 2007-2010, a proporção não chega a 10\%. Assim como há redução no número de PECs sobre as regras políticas apresentadas a partir de 2007, também há diminuição no número de PECs que avançam no processo de tramitação. Os dados sugerem que, nos primeiros cinco anos da Constituição de 1988, os legisladores desprendiam mais esforços em torno da mudança das regras políticas, não apenas apresentando PECs sobre o tema, mas dedicando-se a fazer com que elas avançassem no processo decisório. De 1995 em diante, mas, sobretudo, a partir de 2007, o sucesso dos parlamentares em fazerem essa agenda avançar na Câmara reduz-se de forma dramática.

Vários fatores podem estar associados a essa mudança. Em primeiro lugar, a bastante propalada predominância do Poder Executivo e seu controle sobre a agenda e o ritmo dos trabalhos legislativos pode ter funcionado como um obstáculo para os legisladores. A reforma política, sendo uma agenda do Legislativo, teria perdido espaço para outros temas mais centrais para o Executivo no período, como a reforma administrativa a partir de 1995. A redução ainda mais marcante, a partir de 2003, do número e da 
proporção de PECs com parecer aprovado na CCJC, por sua vez, pode ser reflexo de uma mudança de estratégia dos parlamentares, ao considerarem as dificuldades para realizar alterações nas regras políticas pela via constitucional. De fato, a partir de 2003, o tema da reforma política parece sofrer um deslocamento: de uma grande diversidade de propostas apresentadas via PECs para a concentração em torno de uma dezena de mudanças através de projetos de lei. Essas considerações não teriam impactado necessariamente o volume de PECs apresentadas - que cresce a partir do primeiro governo de FHC até o fim do primeiro governo de Lula - mas os esforços desprendidos pelos parlamentares para verem as PECs aprovadas e o seu sucesso no processo.

A análise temática das PECs que chegaram a ter parecer votado na CCJC e em comissão especial não revela muito. Observa-se a mesma diversidade de temas com destaque para as propostas de mudança do sistema eleitoral, que representam a maior parte das PECs apresentadas. Entre elas, propostas versando sobre duração dos mandatos, estabelecimento da coincidência geral das eleições, introdução do sistema misto, alteração do número de vereadores e de deputados, alteração da idade mínima para se candidatar, entre outras, chegaram a ser votadas em comissão especial em diferentes momentos, sem ir além.

Com exceção das 5 PECs que foram transformadas em emenda constitucional, outras 6 chegaram a ser votadas em plenário em primeiro turno: duas delas versavam sobre alteração no número de vereadores, uma sobre regras para realizar mudanças na legislação eleitoral, duas estabeleciam limites para a elegibilidade e uma versava sobre prerrogativas do Poder Executivo. As 2 PECs que propunham alteração no número de vereadores chegaram a ser votadas em segundo turno. Uma delas, depois de ter sido aprovada em segundo turno no ano de 2008 passou a tramitar no Senado. Mas a mudança só ocorreu um ano depois com a aprovação da PEC n³ 336/2009, com origem no Senado, transformada na Emenda Constitucional no 58, de 2009.

A análise temática das PECs e de seu processo de tramitação dá a impressão de um grande desperdício de tempo e energia dos parlamentares: observa-se uma grande sobreposição de propostas muito similares que, depois de passarem por diversas instâncias decisórias, ou são apensadas a outras PECs ou são prejudicadas em face da aprovação de outra proposta semelhante. Do 
ponto de vista individual, pode ser uma estratégia interessante para o parlamentar que espera auferir alguma vantagem da simples apresentação de uma PEC. As chances de sucesso no processo, no entanto, são muito pequenas.

A mudança das regras do jogo pela via constitucional no país é a exceção e, nos casos em que ocorreu - apenas em cinco ocasiões -, parece ter resultado de circunstâncias e fatores muito particulares. Em todos os casos propostas em pauta já há alguns anos tiveram a tramitação acelerada em determinado momento. A PEC n 51/1990, versando sobre a data de realização do plebiscito sobre a forma e o sistema de governo, e a PEC n ${ }^{\circ} 45 / 1991$, versando sobre o prazo para realização de mudanças na legislação eleitoral demoraram quase dois anos para serem aprovadas. Ambas situam-se nos esforços dos parlamentares, nos primeiros anos após a promulgação da Constituição, para tratar de questões que estavam na ordem do dia. A PEC n ${ }^{\circ} 1 / 1995$, que introduziu a reeleição para os cargos executivos, levou dois anos e 108 dias para ser aprovada, sendo o único caso em que o Executivo mobilizou sua coalizão em prol de uma mudança do sistema eleitoral. A PEC n $347 / 1996$, que versava sobre a interrupção da sessão legislativa apenas depois de ser aprovado o orçamento anual, percorreu um longo caminho da apresentação à aprovação: nove anos e 311 dias. Mais recentemente, motivados pelas manifestações populares que tomaram o Brasil em junho de 2013, os parlamentares aprovaram a PEC $\mathrm{n}^{\circ}$ 349/2001, abolindo a votação secreta no Congresso Nacional nos casos de perda de mandato de deputado ou senador e para apreciação de veto, depois de mais de doze anos da apresentação da proposta ${ }^{15}$.

As dificuldades para levar adiante sua própria agenda de reforma das regras do jogo político, como já assinalado, podem ter contribuído para uma mudança na estratégia dos legisladores. Desde 2003, a reforma política passou a ser pensada a partir de mudanças na legislação ordinária, sendo três os principais momentos desse processo no âmbito da Câmara dos Deputados. O primeiro deles foi a aprovação pela Comissão Especial da Reforma Política do PL N. 2.679/03 que previa a votação em lista partidária preordenada, o fim das coligações eleitorais nas eleições proporcionais, a criação de federações partidárias e o financiamento púbico exclusivo de campanha. O projeto não chegou a ser apreciado em plenário e o tema voltou à pauta anos depois com

15 Outras emendas constitucionais promulgadas no período tiveram origem no Senado como a que estabelecia critérios para a edição de medidas provisórias (EM n 32, de 2001) e a que modificou os critérios para a composição das câmaras municipais (EM n 58, de 2009/ PEC n³36/2009). 
o Projeto de Lei no 1.210/2007. Dessa vez, o projeto foi apreciado em plenário, mas com a rejeição da proposta de introdução da lista partidária preordenada, por 252 votos contra 181, todas as demais propostas foram abandonadas.

O terceiro e último momento remete à formação, em fevereiro de 2011, de uma nova comissão especial na Câmara dos Deputados para tratar do assunto. $\mathrm{O}$ relatório da comissão, mais abrangente do que o da primeira, previa mudanças no sistema de financiamento das campanhas eleitorais, a adoção da lista flexível com a colocação das mulheres em lugares competitivos na lista, o fim das coligações nas eleições proporcionais e a criação das federações partidárias, introdução de mecanismos de democracia interna nos partidos, mudança nos critérios para suplência de senadores, fortalecimento dos mecanismos de democracia participativa, entre outros. Até a conclusão deste artigo, as propostas não haviam entrado na agenda de votações da Câmara dos Deputados.

Embora não tenha ocorrido avanço significativo em relação às propostas de alterações mais centrais do sistema eleitoral, é importante registrar algumas mudanças pontuais realizadas na última década via projetos de lei. Entre elas, a introdução de regras mais rígidas sobre o financiamento das campanhas eleitorais: a Lei $n^{\circ} 11.300$, de 2006, visava coibir o uso de recursos não contabilizados nas campanhas eleitorais, o chamado "Caixa 2", e formas disfarçadas de compra de votos como a distribuição de brindes. A aprovação dessa Lei esteve fortemente associada ao chamado escândalo do mensalão, denunciado em 2005 e amplamente divulgado pela mídia a partir de então.

No ano de 2009, a Lei ${ }^{\circ} 12.034$ introduziu mudanças relativas à autorização de propaganda política e arrecadação de recursos para campanhas pela internet (blogs e redes sociais) e trouxe inovações importantes relativas à participação política das mulheres. Por último, merece destaque a aprovação, em 2010, da chamada Lei da Ficha Limpa (Lei Complementar $n^{\circ}$ 135), resultado de um projeto de lei de iniciativa popular. Esta Lei passou a valer nas eleições de 2012, estabelecendo critérios mais rigorosos para a elegibilidade.

\section{Considerações finais}

O presente artigo abordou o tema da reforma das instituições políticas no Brasil com foco nas Propostas de Emenda à Constituição (PECs) 
apresentadas nas últimas duas décadas. Aventou-se a hipótese de que as propostas de mudança mais radicais teriam perdido espaço na agenda de reformas que seria, agora, dominada por propostas de caráter mais pontual. Essa hipótese confirma-se para as propostas de alteração do sistema de governo. O plebiscito de 1993 parece, nesse sentido, ter contribuído para dar por encerrado o assunto. Uma grande variedade de outros aspectos do sistema, entretanto, continua sendo alvo de propostas de modificação, desde os mais pontuais relativos à idade para se candidatar para os diversos cargos eletivos e à duração dos mandatos até os aspectos mais gerais como o sistema de representação.

A análise mostrou que determinados temas têm tido presença constante na agenda como a questão da duração dos mandatos, a alteração na magnitude dos distritos eleitorais com a modificação do número de parlamentares, a introdução ou extinção da reeleição e do segundo turno e a introdução de eleições coincidentes nos três níveis, federal, estadual e municipal. Outros aspectos perderam espaço, como a introdução do voto facultativo e da fidelidade partidária (esta última devido a uma solução dada pelo Supremo Tribunal Federal em 2007). Ainda assim, não é possível afirmar que esses temas desapareçam por completo da agenda. As inúmeras propostas para extinguir a reeleição consecutiva para os cargos executivos ou para ampliar o mandato de seus ocupantes para cinco anos é um exemplo de que algumas decisões podem ser objeto de tentativas de reversão. Sobretudo, se os procedimentos que as originou for alvo de questionamentos.

Embora o tema da reforma política tenha, ao longo das duas últimas décadas, ocupado espaço de relevo na mídia e no meio acadêmico - em alguns momentos mais que em outros -, verificou-se que, quanto ao volume, as PECs versando sobre alterações da regra do jogo, se nos primeiros anos após a Constituinte representavam mais de um terço do total de PECs, a partir de 1995 cederam espaço para propostas de mudança focadas em outras dimensões, como a econômica e a administrativa. Os dados sobre a procedência e a autoria das PECs mostram também que, a despeito de sua baixa eficácia em aprovar as propostas que origina, o Poder Legislativo é a arena privilegiada de discussão da reforma política.

Um dos achados importantes do levantamento realizado remete às propostas de alteração na distribuição de prerrogativas entre os poderes 
Executivo e Legislativo e de mudança das regras de organização legislativa e do processo legislativo. $\mathrm{O}$ fato de que um quarto das propostas esteja relacionado a esses temas mostra que o debate em torno da reforma política no Brasil não se resume e não deve se resumir a mudanças das regras eleitorais.

Tais propostas permitem, também, problematizar as abordagens que tendem a ver no atual padrão de distribuição de poderes um equilíbrio resultante da racionalidade dos atores políticos (Amorim Neto e Santos, 2003). As propostas para reduzir e restringir as prerrogativas do Executivo e para fortalecer o Legislativo sugerem que esse equilíbrio é menos fruto de uma adesão plena ao arranjo vigente e mais decorrente da distribuição desigual de recursos, que torna difícil para alguns atores políticos a alteração das regras do jogo. Essas colocações, além de remeter à noção de path dependence (Pierson, 2000), permitem questionar o postulado da escolha racional de que a durabilidade das instituições resulta de sua eficiência. Resta a pergunta: eficiente para quem? Aos olhos de alguns atores políticos, o arranjo institucional vigente pode não ser eficiente ao gerar um demasiado predomínio do Executivo na determinação da agenda e do ritmo do processo legislativo. Acontece que, simplesmente, tais atores carecem dos recursos políticos e institucionais necessários ao êxito de suas propostas em face dos custos envolvidos na mudança constitucional.

Por exigir o apoio de amplas maiorias, o sucesso na realização de mudanças pela via constitucional parece depender de uma conjunção de fatores favoráveis e especiais como ampla mobilização e pressão popular ou articulação do Poder Executivo. Diante das dificuldades para fazer avançar a agenda constitucional da reforma, a partir do ano de 2003 viu-se um deslocamento na estratégia dos legisladores: de uma grande diversidade de propostas apresentadas via PECs para a concentração em torno de uma dezena de mudanças por meio de projetos de lei, sendo a maior parte focada no sistema eleitoral.

Os achados registrados no artigo remetem a uma agenda de pesquisa a ser desenvolvida no futuro. A inclusão, na análise, das PECs de autoria dos senadores e das que tratam de questões atinentes ao pacto federativo contribuiriam para tornar a análise mais completa. A análise da direção das reformas - se no sentido de tornar o sistema mais inclusivo e mais representativo ou mais restritivo, de ampliar o equilíbrio entre os poderes etc. 
- representaria um avanço analítico importante. Por último, a comparação com a agenda de reformas das regras do jogo em outros países permitiria ampliar a compreensão sobre as singularidades do caso brasileiro.

\section{Referências bibliográficas}

AMES, Barry (2001). The deadlock of democracy in Brazil. Ann Arbor: The University of Michigan Press.

AMORIM Neto, Octavio (2000), "Gabinetes presidenciais, ciclos eleitorais e disciplina legislativa no Brasil”. Dados, v. 43, n. 3, p. 479-519.

AMORIM NETO, Octavio \& SANTOS, Fabiano (2003). "O segredo ineficiente revisto: o que propõem e o que aprovam os deputados brasileiros". Dados, v. 46, n. 4, p. 661-98.

AMORIM Neto, Octavio; CORTEZ, Bruno Freitas \& PESSOA, Samuel de Abreu (2011). "Redesenhando o Mapa Eleitoral do Brasil: uma proposta de reforma política incremental”. Opinião Pública, v. 17, n. 1, p. 45-75.

ANASTASIA, Fátima; MELO, Carlos Ranulfo F. de \& SANTOS, Fabiano (2004). Governabilidade e representação política na América do Sul. Rio de Janeiro: Konrad-Adenauer-Stiftung; São Paulo: Editora Unesp.

ARAÚJO, Paulo Magalhães (2011). "Recrutamento parlamentar para o Senado e o perfil dos senadores brasileiros, 1989-2006”. Revista Política Hoje, v. 20, n. 2, p. 550-80.

AVRITZER, Leonardo (2006). “Reforma política e participação no Brasil”, em AVRITZER, Leonardo \& ANASTASIA, Fátima (orgs.). Reforma política no Brasil. Belo Horizonte: Editora da UFMG.

AVRITZER, Leonardo \& ANASTASIA, Fátima (orgs.). Reforma política no Brasil. Belo Horizonte: Editora da UFMG.

BENEVIDES, Maria Vitória; VANNUCHI, Paulo \& KERCHE, Fábio (orgs.) (2003). Reforma política e cidadania. São Paulo: Fundação Perseu Abramo.

BOIX, Charles (1999). "Setting the rules of the game: the choice of electoral systems in advanced democracies". American Political Science Review, v. 93, n. 3, p. 609-24.

BRASIL (1988-2010). Sistema de Informação Legislativa (Sileg). Câmara dos Deputados. Disponível em: < $\underline{\text { http://www.camara.leg.br/sileg }>\text {. Acesso }}$ em: 4 mar. 2015. 
BRUSSI, Antônio. (2008). “Reforma política: para onde vai?”, em MUHHOLAND, Timothy \& RENNÓ, Lúcio (orgs.). Reforma politica em questão. Brasília: Editora UnB. p. 107-12.

CINTRA, Antônio Octávio (2008). "Reforma política: mudando os termos da 'conexão eleitoral', em MULHOLLAND, Timothy \& RENNÓ, Lúcio (orgs.). Reforma política em questão. Brasília: Editora UnB. p. 59-69.

COLOMER, José M. (2005) "It's parties that choose electoral systems (or Duverger's laws upside down)”. Political Studies, v. 53, n. 1, p. 1-21. COUTO, Claudio G. (2006). "Emendas constitucionais", em AVRITZER, Leonardo \& ANASTASIA, Fátima (orgs.). Reforma política no Brasil. Belo Horizonte: Editora da UFMG.

COUTO, Claudio G. \& ARANTES, Rogério B. (2006). "Constituição, governo e democracia no Brasil”. Revista Brasileira de Ciências Sociais, v. 1, n. 61, p. $41-62$.

DONOVAN, Mark (1995). "The politics of electoral reform in Italy". International Political Science Review, v. 16, n. 1, p. 47-64

FIGUEIREDO, Argelina M. C; LIMONGI, Fernando (1999). Executivo e Legislativo na nova ordem constitucional. Rio de Janeiro: FGV Editora. (2006). "Poder de agenda na democracia brasileira: desempenho do governo no presidencialismo pluripartidário", em SOARES, Gláucio \& RENNÓ, Lucio (eds.). Reforma política: lições da história recente. Rio de Janeiro: FGV Editora.

JONES, M. P. (1994). "Presidential election laws and multipartism in Latin America”. Political Research Quarterly, Utah, v. 47, n. 1, p. 41-57.

LAMOUNIER, Bolívar (1989). Partidos e utopias: o Brasil no limiar dos anos 90. São Paulo: Loyola.

LIJPHART, Arend (1994). Electoral systems and party systems. A study of twenty seven democracies, 1945-1990. Oxford, Oxford University Press. (2003). Modelos de democracia: desempenho e padrões de governo em 36 países. Rio de Janeiro: Civilização Brasileira.

LIJPHART, Arend \& GROFMAN, B. (eds.) (1984). "Choosing an electoral system", em Choosing an electoral system: issues and alternatives. New York: Praeger.

LINZ, Juan \& VALENZUELA, A. (1994). The failure of presidential democracy. Baltimore; London: The Johns Hopkins University. 
MAINWARING, Scott (1993). "Presidentialism, multipartism and democracy: the difficult combination". Comparative Political Studies, v. 26 , n. 2, p. 198-228.

MAINWARING, Scott \& SHUGART, Matthew S. (1997). Presidentialism and democracy in Latin America. Cambridge: Cambridge University Press.

MAYHEW, David (2006) "Actions in the public sphere", em QUIRK, Paul. J. \& BINDER, Sarah A. (eds.). Institutions of American democracy: the legislative branch. Oxford University Press.

MELO, Carlos Ranulfo (2004). Retirando as cadeiras do lugar: migração partidária na Câmara dos Deputados (1985/2002). Belo Horizonte: Editora da UFMG.

MELO, Marcus A. (2005). "O sucesso inesperado das reformas de segunda geração: federalismo, reformas constitucionais e política social”. Dados, v. 48 , n. 4 , p. $845-89$.

MIGUEL, Luis Felipe \& MACHADO, Carlos (2010). "De partido de esquerda a partido do governo. O PT e suas coligações para prefeito (2000-2008)", em KRAUSE, Silvana, DANTAS, Humberto \& MIGUEL, Luis Felipe (orgs.). Coligações partidárias na nova democracia brasileira: perfis e tendências. São Paulo: Editora Unesp; Rio de Janeiro: Fundação Konrad Adenauer.

MULHOLLAND, Timothy \& RENNÓ, Lúcio (orgs.). Reforma política em questão. Brasília: Editora UnB.

NEGRETTO, Gabriel (2009). "Paradojas de La reforma constitucional em América Latina”. Journal of Democracy en Español, v. 1, n. 1, p. 38-54.

NICOLAU, Jairo (1997). "As distorções na representação dos estados na Câmara dos Deputados brasileira”. Dados, v. 40, n. 3, p. 453-516.

(2004). Sistemas eleitorais. 5. ed. rev. e atualiz. Rio de Janeiro: FGV Editora.

NORRIS, Pippa (1997). "Choosing electoral systems: proportional, majoritarian and mixed systems". International Political Science Review, v. 18, n. 3, p. 297-312.

PIERSON, Paul (2000). “The limits of design: explaining institutional. Origins and change". International Journal of Policy and Administration, v. 13, n. 4, p. 475-99.

PRAÇA, Sérgio \& DANTAS, Humberto (2006). "Pequenos partidos no Brasil: uma análise do posicionamento ideológico com base nas 
coligações municipais de 2000 a 2008”, em KRAUSE, Silvana, DANTAS, Humberto \& MIGUEL, Luis Felipe (orgs.). Coligações partidárias na nova democracia brasileira: perfis e tendências. São Paulo: Editora Unesp; Rio de Janeiro: Fundação Konrad Adenauer.

RENNÓ, Lúcio (2008). "Reformas políticas no Brasil: realizadas e prováveis", em MUHHOLAND, Timothy \& RENNÓ, Lúcio (orgs.). Reforma politica em questão. Brasília: Editora UnB. p. 13-42.

SCHMIDT, Benício V. (2008). “A reforma política em questão?”, em MUHHOLAND, Timothy \& RENNÓ, Lúcio (orgs.). Reforma política em questão. Brasília: Editora UnB. p. 53-57.

SOARES, Gláucio (2006). "Reforma constitucional", em AVRITZER, Leonardo \& ANASTASIA, Fátima (orgs.). Reforma política no Brasil. Belo Horizonte: Editora da UFMG.

SOARES, Gláucio \& RENNÓ, Lucio (orgs.) (2006). Reforma política: lições da história recente. Rio de Janeiro: FGV Editora.

TAAGEPERA, Rein \& SHUGART, Matthew S. (1989). Seats and votes: the effects and determinants of electoral systems. New Haven; London: Yale University Press.

ZOVATTO, Daniel \& HENRÍQUEZ, Jesús O. (2008). "Reforma política y electoral en América Latina 1978-2007: lectura regional comparada", em Reforma política y electoral em América Latina 1978-2007. México: Universidad Nacional Autónoma de México; Idea - The International Institute for Democracy and Electoral Assistance. Disponível em: $<$ http:// www.idea.int/publications/perla/index.cfm>. Acesso em: 2 mar. 2015.

\section{Resumo}

O tema da reforma política tem ocupado espaço importante nos debates políticos, seja na academia, na mídia ou entre as elites parlamentares brasileiras. Apesar disso, não se têm um inventário das propostas de mudança que permita avaliar quais temas têm ganhado e quais têm perdido espaço no debate sobre a reforma das instituições políticas no país. Este artigo busca contribuir para superar essa lacuna ao analisar as Propostas de Mudança à Constituição (PECs) apresentadas no período de 1988 a 2010, seus autores e objetivos e o êxito dos diferentes atores no avanço do processo de discussão e votação das propostas apresentadas.

Palavras-chave: reforma política, Propostas de Emenda à Constituição, representação política. 


\section{Abstract}

The issue of political reform has received considerable attention in political debates among scholars, media and parliamentary elites in Brazil. Nevertheless, we do not have an inventory of change proposals that allows us to access which issues have gained and which have lost ground in the debate on reforming political institutions in the country. This article aims to overcome this gap by analyzing the Constitutional Amendments Proposals (PECs) presented in 1988-2010, including their authors and their goals, as well as the success of different players in advancing the process of discussion and voting those proposals. Keywords: political reform, constitutional amendments proposals, political representation.

Recebido em 18 de outubro de 2013.

Aprovado em 4 de abril de 2014. 